\title{
患者をみる 人をみる
}

\author{
岡本さやか \\ 藤田医科大学医学部リハビリテーション医学 II 講座 \\ 藤田医科大学七栗記念病院
}

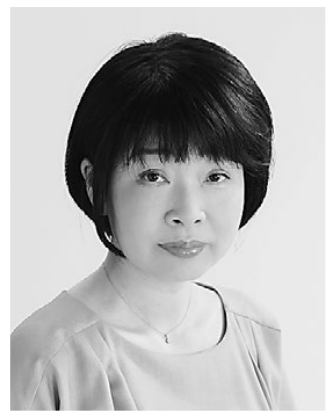

世界中で新型コロナウイルスが猛威を奮ってい ます．第 1 波が過ぎ去ったと思うまもなく，第 2 波 による患者増加, 感染拡大が現在も続いています. 日々医療の最前線で患者さんの治療に尽力されて いる医療従事者の皆様に, 深く感謝を申し上げま す．また，罹患されたすべての方々が 1 日も早く 回復されるよう㧍祈り申し上げます。この原稿が 揭載される頃には，少しでも終息に向かっているこ とを願ってやみません.

さて，私の趣味は読書です，今まで多くの本を 読んできた中で, 一番心に残ったのは, 山本周五 郎著『樅ノ木は残った』です。これは，江戸時代前 期に仙台藩伊達家で起こったお家騒動を題材とし ており，原田家当主原田甲斐宗輔が江戸幕府によ る取り潰しから藩を守るために尽力した物語です. 確か, 最初に読んだのは中学 3 年頃だったかと思 います，中学生にとっては, 難しい表現も多く, 読 み終えるまでに時間がかかりましたが，読み終えた ときには，主人公の生き様に感動し，涙が止まりま せんでした. しかし，読んで数年経ったときに，実 はこの物語は作家の創作であり, 歴史上, 原田甲 斐宗輔は伊達騒動の当事者の 1 人であり, 悪人と されていることを知りました。 1660 年仙台藩では 主君の伊達綱宗が逼塞となり, 嫡子の伊達綱村が 伊達家当主となりましたが, 綱村は 2 歳と幼少だっ たため後見として伊達宗勝が命ぜられました，そ の宗勝と対立していた伊達宗重が宗勝らの専横を 江戸幕府に上訴すると, 1671 年 3 月 27 日, 宗輔は
幕府の評定を受けるため, 他 5 人の仙台藩家臣と 騒動解決を目的として大老・酒井忠清邸に召喚さ れました，その評定の席で，劣勢となった宗輔は, 同じく召喚されて来ていた伊達宗重をその場で斬 殺し, さらに宗重派の柴田朝意と斬りあって傷を 負い死亡したということになっています。この事実 を知ったときに, 同じ人生, 同じ人間でも見方を変 えるとまったく見え方が違うのだということを知 り,「人をみる」ことの難しさを学びました.

私は医者になって数年間神経内科医として過ご し, その後にリハビリテーション科医となりました。 リハビリテーション医療は活動を育む医学とされ ています。リハビリテーション科医になって, 患者 さんの生活活動を知ることの重要さを学びました. 患者さんの機能障害を評価することはもちろんで すが，患者さんの生活活動を考えるにあたっては, 「患者さんをみる」だけでなく,「その人をみる」必 要があると思います。そのためには，患者さんや家 族を 1 つの面だけから判断するのではなく, 見方を 変え, いろいろな面から見直し, 可能性を考える必 要があります.

新型コロナウイルス感染症が蔓延している今, 当院でも面会禁止が続いており, 患者さんやその 家族はかなりのストレスを抱えて過ごしています. その中で, 少しでも効果的なリハビリテーション治 療が行えるように, 早期に家族との生活に戻れるよ うに,「人をみる」ことの重要性がより求められて いると感じています. 